\title{
SITOTOKSISITAS DAN INDUKSI APOPTOSIS EKSTRAK ETANOL TERIPANG Holothuria atra JAEGER, 1833 PADA BEBERAPA SEL KANKER
}

\section{Cytotoxicity and Apoptosis Induction of Ethanol Extract Holothuria atra Jaeger, 1833 on Cancer Cells}

\author{
Ernie Halimatushadyah', Muhammad Da'i', dan Muhammad Nursid ${ }^{2 \star}$ \\ ${ }^{1}$ Magister Farmasi, Sekolah Pasca Sarjana, Universitas Muhammadiyah Surakarta, \\ JI. A. Yani Tromol Pos I Surakarta, Jawa Tengah, Indonesia \\ ${ }^{2}$ Balai Besar Riset Pengolahan Produk dan Bioteknologi Kelautan dan Perikanan, Badan Riset dan Sumber Daya Manusia \\ Kelautan dan Perikanan, JI. KS.Tubun Petamburan VI Jakarta Pusat, Indonesia \\ *Korespondensi Penulis: muhammadnursid@gmail.com
}

Diterima: 21 Juni 2018; Direvisi: 31 Oktober 2018; Disetujui: 20 Desember 2018

\begin{abstract}
ABSTRAK
Teripang Holothuria atra merupakan biota laut yang banyak ditemukan di perairan Indonesia yang termasuk dalam filum Echinodermata dan berpotensi sebagai antikanker. Penelitian ini bertujuan untuk mengetahui sitotoksisitas dan induksi apoptosis ekstrak etanol teripang $\mathrm{H}$. atra secara in vitro terhadap beberapa sel lestari. Pengujian sitotoksisitas dilakukan dengan metode MTT (3-(4,5-dimethylthiazol-2-yl)-2,5-diphenyl tetrazolium bromide) menggunakan sel HeLa, T47D, WiDr dan sel normal Vero, sedangkan uji induksi apoptosis dilakukan terhadap sel dengan hasil uji sitotoksisitas terbaik menggunakan metode flowcytometry dan double staining. Hasil penelitian menunjukkan bahwa ekstrak etanol teripang $H$. atra mampu menghambat pertumbuhan sel kanker HeLa, T47D dan WiDr. Nilai IC ${ }_{50}$ ekstrak $H$. atra terhadap ketiga sel tersebut masingmasing sebesar $41,06 \pm 4,21 ; 20,89 \pm 1,55 ; 26,50 \pm 4,43 \mu \mathrm{g} / \mathrm{ml}$ tetapi esktrak tersebut memiliki sitotoksisitas yang lebih rendah terhadap sel Vero $\left(\mathrm{IC}_{50}\right.$ sebesar 128,00). Analisis flowcytometry dan double staining pada sel T47D memperlihatkan bahwa ekstrak etanol teripang H.atra mampu menginduksi apoptosis pada sel tersebut.
\end{abstract}

KATA KUNCl: teripang, Holothuria atra, sitotoksisitas, induksi apoptosis

\section{ABSTRACT}

Holothuria atra is the marine organism found in Indonesian waters which is included in the phylum of Echinodermata and has the potential as an anticancer. This research aims to determine the cytotoxicity and apoptosis induction of ethanol extract of sea cucumber $\underline{H}$. atra in vitro on cancer cell lines. This cytotoxicity test was conducted by MTT (3-(4,5-dimethylthiazol-2-yl)-2,5diphenyl tetrazolium bromide) assay using HeLa, T47D, and WiDr cancer cell lines while apoptosis induction test was conducted on cell which had the best cytotoxicity result by flowcytometry and double staining. The results showed that ethanol extract of $\underline{H}$. atra was able to inhibit the growth of HeLa, T47D and WiDr cell lines with $I C_{50}$ of $41,06 \pm 4,21 ; 20,89 \pm 1,55 ; 26,50 \pm 4,43 \mu \mathrm{g} / \mathrm{ml}$ respectively, however, the extract had lower cytotoxicity to normal Vero cells. Flowcytometry and double staining analysis showed that ethanol extract of sea cucumber $\underline{H}$. atra was able to induce apoptosis in T47D cell.

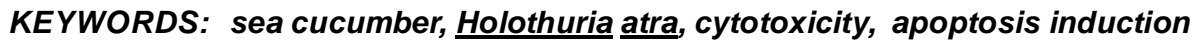

\section{PENDAHULUAN}

Kanker adalah penyakit yang ditandai dengan pertumbuhan sel secara abnormal yang dapat menyerang bagian tubuh atau organ lain (WHO, 2018). Data yang diperoleh dari World Health Organization (WHO) pada tahun 2015, sekitar 8,8 juta kematian disebabkan oleh kanker. Jumlah kasus ini diperkirakan akan meningkat menjadi 17 juta kematian per tahun pada tahun 2030 (Donepudi et al., 2014). Terapi yang dapat dilakukan untuk mengatasi kanker antara lain: kemoterapi, radioterapi, terapi antiendokrin, terapi target khusus, dan operasi (Mulrane et al., 2013). Penggunaan agen kemoterapi yang berkepanjangan dapat menimbulkan efek samping dan resistensi karena kurang selektifnya agen kemoterapi terhadap 
sel kanker (Rachmani \& Sehesti, 2012). Pada saat ini pemanfaatan produk bahan alam telah menjadi alternatif dan banyak diminati dalam pengobatan kanker (Hussain, Fareed, Ansari, \& Sajid, 2012).

Sebagian besar wilayah Indonesia, sekitar $75 \%$ merupakan wilayah kelautan. Keanekaragaman hayati perairan laut Indonesia memberi peluang untuk memanfaatkan biota laut dalam pencarian metabolit sekunder senyawa bioaktif baru (Chasanah, 2008). Salah satu biota laut yang banyak ditemukan di perairan Indonesia adalah teripang atau timun laut yang termasuk dalam filum Echinodermata (Bordbar, Anwar, \& Saari, 2011). Teripang memiliki senyawa metabolit sekunder antara lain flavonoid, fenol, terpenoid, saponin dan alkaloid (Dhinakaran \& Lipton, 2014). Triterpen glikosida yang termasuk dalam senyawa saponin pada teripang dilaporkan memiliki efek biologis antara lain sebagai antijamur, antioksidan, dan antikanker (Li, Himaya, \& Kim, 2013).

Aktivitas antikanker dapat ditunjukkan dengan nilai inhibition concentration $50\left(\mathrm{IC}_{50}\right)$, nilai $\mathrm{IC}_{50}$ merupakan konsentrasi yang menghasilkan hambatan proliferasi sel sebesar $50 \%$ dan menunjukkan potensi suatu senyawa untuk dimanfaatkan dalam terapi kanker. Metode umum yang digunakan dalam pengukuran nilai $\mathrm{IC}_{50}$, yaitu uji methylthiazoldiphenyl tetrazolium (MTT), sedangkan untuk mengetahui mekanisme kematian sel dapat dilakukan dengan pengujian induksi apoptosis. Induksi apoptosis pada sel kanker menjadi suatu hal yang menjanjikan dalam pengobatan kanker karena sel kanker akan mengalami bunuh diri secara spesifik tanpa mengganggu sel sehat dan tidak menimbulkan inflamasi (Wong, 2011). Althunibat et al., (2013) melaporkan bahwa ekstrak akuades Holothuria edulis dapat menghambat sel kanker TE1 dengan $\mathrm{IC}_{50} 78,0 \mu \mathrm{g} / \mathrm{ml}$ dan $\mathrm{A} 549$ dengan $\mathrm{IC}_{50} 132,0$ $\mu \mathrm{g} / \mathrm{ml}$. Peneliti lain juga melaporkan bahwa komponen asam lemak jenuh dari teripang Holothuria sp. mampu menghambat sel MCF-7 dengan $I_{50} 10,32$ ppm (Chasanah, Januar, \& Nursid, 2014).

Penggunaan sel lestari untuk pengujian sitotoksik sekarang ini semakin diminati karena dengan menggunakan sel, mekanisme toksisitas biokimia dapat dikerjakan lebih efektif dan kondisi lingkungan sel mudah dikontrol. Pengembangan metode in vitro sebagai alternatif pengganti uji dengan menggunakan hewan uji mempunyai relevansi yang cukup baik yang bertujuan untuk mendeteksi potensi suatu obat pada manusia (Freshney, 2005).

Pada Penelitian ini dilakukan pengujian sitotoksisitas ekstrak teripang Holothuria atra yang merupakan salah satu jenis teripang yang banyak ditemukan di Perairan Indonesia (Husain, Tamanampo \& Manu, 2017) terhadap sel kanker serviks (HeLa), sel kanker payudara (T47D), dan sel kanker kolon
(WiDr). Jenis sel tersebut digunakan dalam penelitian ini karena kanker tersebut paling banyak diderita dan paling banyak penyebab utama kematian akibat kanker pada wanita (Kemenkes, 2013). Penelitian ini bertujuan unutk mengetahui sitotoksitas dan induksi apoktosis ekstrak etanol teripang $H$. atra terhadap beberapa sel lestari kanker.

\section{BAHAN DAN METODE}

\section{Bahan}

Simplisia yang digunakan adalah teripang $(H$. atra) segar yang diperoleh dari Perairan Jailolo, Halmahera, Maluku Utara, kemudian dideterminasi di Pusat Penelitian Oseanografi LIPI, Jakarta. Teripang yang digunakan pada penelitian ini merupakan teripang segar yang berukuran $10-20 \mathrm{~cm}$. Teripang dicuci dan dibuang viscera atau bagian pencernaannya. Sel uji yang digunakan pada penelitian ini adalah beberapa sel kanker yaitu sel HeLa (sel kanker leher rahim), T47D (sel kanker payudara), WiDr (sel kanker kolon) dan sel Vero (sel normal ginjal monyet hijau Afrika) dari Laboratorium Parasitologi, Fakultas Kedokteran, Universitas Gajah Mada, Yogyakarta. Penelitian telah mendapatkan persetujuan ethical clearance dari Fakultas Kedokteran Universitas Gajah Mada, Yogyakarta.

\section{Metode}

\section{Ekstraksi}

Simplisia yang digunakan dalam pengujian ini adalah simplisia segar (3365,9 g). Ekstraksi dilakukan dengan cara maserasi, simplisia $H$. atra dalam etanol $96 \%$ dengan perbandingan $1: 2$. pada bejana kaca, ditutup rapat dan dibiarkan selama 24 jam. Selama proses perendaman dilakukan pengadukan beberapa kali, kemudian disaring dengan menggunakan kertas saring. Ampas yang diperoleh direndam kembali dengan pelarut etanol yang baru (kurang lebih 6 kali perlakuan). Maserat yang diperoleh secara keseluruhan dipekatkan dengan rotari evaporator hingga kental. Kemudian dipindahkan ke dalam konikel dan dikeringkan dengan freeze dryer.

\section{Identifikasi kandungan metabolit sekunder}

Identifikasi metabolit sekunder yang tekandung dalam ekstrak etanol teripang $(H$. atra) meliputi pemeriksaan steroid, triterpenoid, flavonoid, alkaloid, dan saponin dengan prosedur mengikuti protokol yang tertera dalam Harbone (1987).

\section{Uji sitotoksisitas dengan metode MTT assay}

Uji sitotoksisitas dilakukan menurut metode Nursid, Chasanah, Murwantoko, dan Wahyouno (2011) 
dengan sedikit modifikasi. Suspensi sel sebanyak 1 $x 10^{4}$ sel dalam media kultur lengkap dimasukkan sebanyak $100 \mu \mathrm{l}$ ke dalam mikroplat 96 sumuran. Sel yang telah terdistribusi tersebut dimasukkan ke dalam inkubator $\mathrm{CO}_{2}$ pada suhu $37^{\circ} \mathrm{C}$. Setelah semalam, media yang berisi sel tersebut dibuang kemudian dimasukkan seri konsentrasi zat uji ke dalam sumuran sebanyak $100 \mu \mathrm{l}$. Mikroplat kemudian diinkubasi kembali ke dalam incubator $\mathrm{CO}_{2}$ selama 24 jam untuk melihat efek sitotoksik. Menjelang akhir inkubasi, kondisi sel didokumentasi untuk setiap perlakuan. Selanjutnya disiapkan MTT $(0,5 \mathrm{mg} / \mathrm{ml})$. Mikroplat dikeluarkan dari inkubator $\mathrm{CO}_{2}$ dan media yang berisikan perlakuan tersebut dibuang dan ditambahkan $100 \mu \mathrm{l}$ MTT ke dalam setiap sumuran, termasuk kontrol sel dan kontrol media. Sel tersebut kemudian diinkubasi di inkubator $\mathrm{CO}_{2}$ selama 2-4 jam. Kondisi sel setelah pemberian MTT diamati dengan mikroskop inverted untuk melihat formazan yang telah terbentuk. Jika formazan sudah terbentuk reaksi MTT dihentikan dengan menambahkan Sodium Dedosil Sulfat (SDS) $10 \%$. Mikroplat diinkubasi di tempat gelap pada suhu kamar semalam. Absorbansi masing-masing sumuran dibaca dengan mikroplat reader pada panjang gelombang $560 \mathrm{~nm}$ (Biorad). Data absorbansi tiap sumuran digunakan untuk menghitung viabilitas sel. Analisis regresi linear digunakan untuk menghitung $\mathrm{IC}_{50}$.

Sel yang digunakan pada pengujian ini adalah sel HeLa, T47D, WiDr dan sel normal Vero sebagai pembanding. Uji dilakukan sebanyak satu kali dengan 3 replikasi dan dilakukan pengujian pendahuluan untuk menentukan konsentrasi ekstrak teripang $H$. atra. Selektivitas ditentukan dengan menggunakan parameter SI (Selectivity Index) dengan cara membagi nilai $\mathrm{IC}_{50}$ pada sel normal dengan $\mathrm{IC}_{50}$ sel kanker (Sutejo, Putri, \& Meiyanto, 2016). Sel yang memiliki nilai IC ${ }_{50}$ dan SI yang terbaik lalu digunakan untuk uji selanjutnya untuk mengetahui efek ekstrak teripang dalam kemampuan menginduksi apoptosis.

\section{Uji Apoptosis dengan analisis flowcytometric}

Uji dilakukan menurut metode Nursid et al. (2011). Setelah sel diberi perlakuan dengan sampel uji dan doksorubisin sebagai kontrol positif selama 24 jam, sel dipanen. Sel dipanen dengan menambahkan $1 \mathrm{ml}$ Phospate Buffer Saline (PBS) kemudian di tampung ke dalam tabung konikel setelah itu di tambah $150 \mu \mathrm{l}$ tripsin-EDTA 0,25\% dan diinkubasi selama 3 menit. Setelah sel terlepas, ditambahkan $1 \mathrm{ml}$ media kultur kemudian diresuspensi, ke dalam campuran lalu ditambahkan $2 \mathrm{ml}$ PBS. Sel disentrifugasi dengan kecepatan 2000 rpm selama 5 menit. Supernatan dibuang dan pelet yang diperoleh ditambahkan $1 \mathrm{ml}$ PBS, dihomogenkan lalu dipindahkan ke dalam tabung mikro. Tabung mikro disentrifugasi dengan kecepatan 2000 rpm selama 3 menit kemudian diberi perlakuan dengan $100 \mu$ I Annexin-V-FLUOS staining kit. Inkubasi dilakukan di dalam ruang gelap selama 10 menit pada suhu $25-27^{\circ} \mathrm{C}$. Histogram sel-sel apoptosis dan nekrosis dianalisis dengan flowcytometer (Becton-Dickinson).

\section{Uji Apoptosis dengan Metode Double Staining}

Uji dilakukan menurut metode Kwan et al. (2015). Disiapkan sejumlah cover slip kemudian dimasukkan ke dalam mikroplat 24 sumuran. Suspensi sel yang telah dihitung jumlahnya $\left(5 \times 10^{5} \mathrm{sel}\right)$ dalam media kultur lengkap ditransfer sebanyak $1 \mathrm{ml}$ ke atas cover slip. Sel yang telah terdistribusi tersebut dimasukkan ke dalam inkubator $\mathrm{CO}_{2}$ pada suhu $37^{\circ} \mathrm{C}$ selama semalam. Setelah semalam, media yang berisi sel tersebut dibuang dan sampel uji dimasukan kedalam sumuran sebanyak $1 \mathrm{ml}$. Mikroplat kemudian diinkubasi selama 10 jam dalam inkubator $\mathrm{CO}_{2}$. Mikroplat yang telah selesai diinkubasi dikeluarkan dari inkubator kemudian media pada sumuran dibuang. Sel dalam sumuran dicuci dengan PBS sebanyak 1 $\mathrm{ml}$. PBS dari sumuran dibuang dengan mikropipet secara perlahan. Cover slip diambil dengan hati-hati kemudian diletakan diatas objek glass. Sebanyak 10 $\mu \mathrm{l}$ reagen campuran etidium bromida - akridin orange diteteskan diatas cover slip. Sel kemudian diamati dibawah mikroskop fluorosen (Olympus).

\section{HASIL DAN PEMBAHASAN}

\section{Ekstraksi Teripang}

Ekstrak kering yang dihasilkan sebesar $25,9 \mathrm{~g}$ dengan rendemen sebesar 0,77\%. Azwanida (2015) menyatakan bahwa hasil ekstrak yang diperoleh dapat dipengaruhi oleh beberapa faktor seperti metode yang digunakan, pelarut, temperatur, perbandingan pelarut serta lamanya waktu ekstraksi.

\section{Identifikasi Kandungan Metabolit Sekunder}

Ekstrak etanol teripang H.atra menunjukkan adanya kandungan triterpenoid, flavonoid, alkaloid, dan saponin. Pengamatan identifikasi kandungan metabolit sekunder dapat dilihat pada Tabel 1.

Hasil pengamatan menunjukkan adanya kesesuaian dengan penelitian Dhinakaran dan Lipton (2014) yang menjelaskan bahwa ekstrak H.atra mengandung flavonoid, fenol, terpenoid, saponin dan alkaloid. Caulier, Dyck, Gerbaux, Eeckhaut, dan Flammang (2011) melaporkan bahwa kandungan saponin pada teripang $H$. atra banyak terdapat pada bagian dinding tubuhnya. Beberapa jenis saponin 
Tabel 1. Identifikasi metabolit sekunder yang terkandung dalam ekstrak etanol teripang $H$. Atra Table 1. Identification of secondary metabolites in ethanol extract sea cucumber $\underline{H}$. atra

\begin{tabular}{lll}
\hline $\begin{array}{c}\text { Golongan Metabolit Sekunder/ } \\
\text { Secondary Metabolite Group }\end{array}$ & \multicolumn{1}{c}{ Pengamatan/Observation } & Hasil/Result \\
\hline Steroid & $\begin{array}{l}\text { Terbentuk warna biru atau ungu/Blue or purple } \\
\text { colour was formed } \\
\text { Terbentuk warna merah/Red colour was formed }\end{array}$ & Negatif/Negative (-) \\
Triterpenoid & $\begin{array}{l}\text { Terbentuk warna merah atau jingga/Red or } \\
\text { orange colour was formed }\end{array}$ & Positif/Positive (+) \\
Flavonoid & $\begin{array}{l}\text { Terbentuk endapan putih atau coklat/White or } \\
\text { brown deposits were formed }\end{array}$ & Positif/Positive (+) \\
Alkaloid & Terbentuk buih/Foamwas formed & Positif/Positive (+) \\
\hline Saponin & &
\end{tabular}

(triterpen glikosida) dari teripang yang telah teridentifikasi, antara lain: holothurin $\mathrm{B}_{1}$, holothurin $\mathrm{B}_{2}$, holothurin $\mathrm{B}_{3}$ dan holothurin $\mathrm{B} / \mathrm{B}_{4}$ yang memiliki aktivitas sebagai antikanker.

\section{Sitotoksisitas Ekstrak Teripang}

Sitotoksisitas ekstrak teripang dalam penelitian ini diuji dengan metode MTT. Metode ini dapat digunakan untuk mengukur proliferasi sel secara kolorimetri. Metode ini berdasarkan pada perubahan garam tetrazolium 3-(4,5-dimethylthiazol-2-yl)-2,5diphenyl tetrazolium bromide (MTT) menjadi kristal formazan dalam mitokondria yang aktif pada sel hidup. Kristal formazan yang terbentuk dapat dilarutkan dengan pelarut tertentu yang kemudian absorbansinya dapat dibaca dengan microplate reader pada panjang gelombang $560 \mathrm{~nm}$ (Ebada, Edrada, Lin, \& Proksch, 2008).

Dalam penelitian ini, konsentrasi larutan uji ekstrak etanol teripang $H$. atra yang digunakan yaitu 7,14 , $21,28,35,42,49 \mu \mathrm{g} / \mathrm{ml}$. Penggunaan konsentrasi pada zat uji tersebut berdasarkan orientasi konsentrasi sebelumnya. Hasil pemberian larutan uji pada konsentrasi rendah yaitu $7 \mu \mathrm{g} / \mathrm{ml}$ menunjukkan

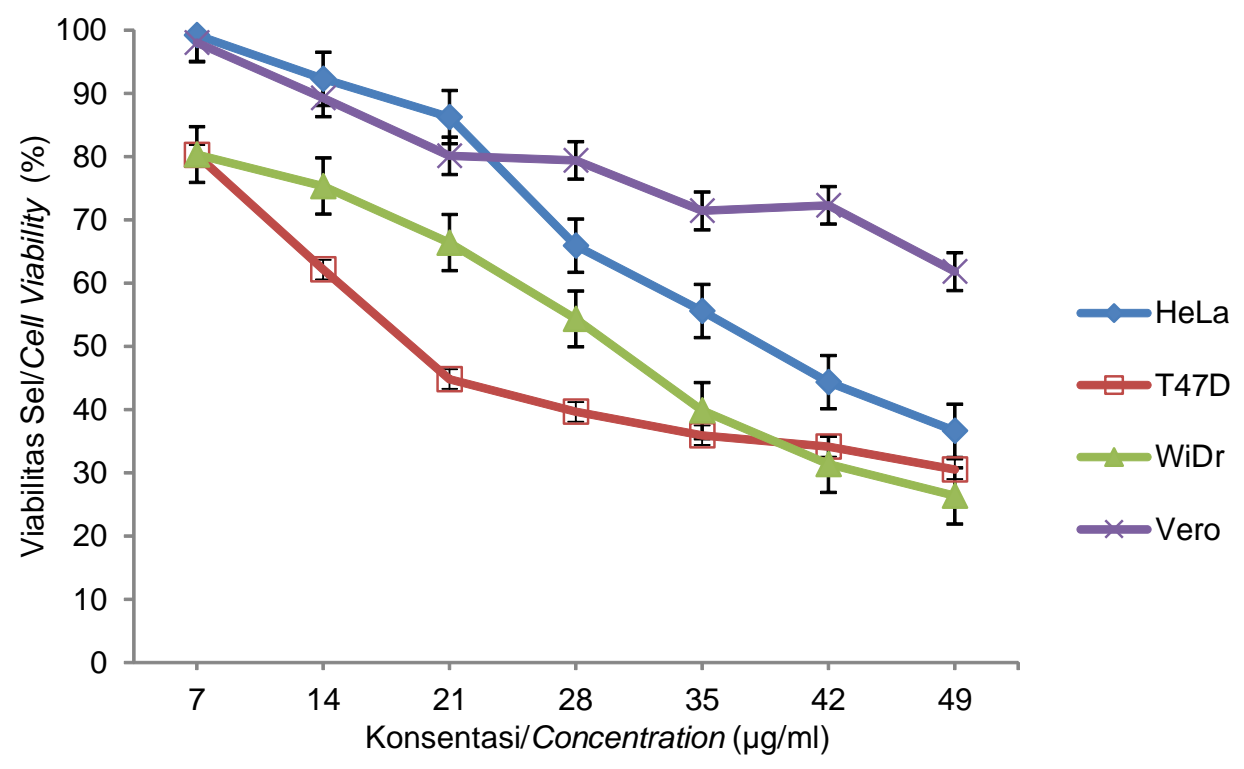

Gambar 1. Uji sitotoksisitas ekstrak ethanol $H$. atra terhadap sel HeLa, T47D, Widr dan Vero dengan berbagai konsentrasi

Figure 1. Cytotoxicity of ethanol extract of $\underline{H}$ atra against HeLa, T47D, Widr and Vero cell lines at various concentrations 
populasi sel yang hidup masih banyak berkisar 80 $100 \%$, sedangkan dengan meningkatnya konsentrasi, sel yang hidup semakin berkurang (Gambar 1). Aktivitas sitotoksik dapat ditandai dengan adanya perubahan morfologi sel. Perubahan morfologi yang telah diberi perlakuan dibandingkan dengan sel kontrol dapat diamati melalui mikroskop. Hasil pengamatan sel HeLa, T47D, WiDr dan sel Vero yang telah diberi perlakuan ekstrak pada salah satu seri konsentrasi yang digunakan yaitu $21 \mu \mathrm{g} / \mathrm{ml}$ dapat dilihat pada Gambar 2.

Berdasarkan National Cancer Institute, ekstrak dinyatakan aktif memiliki aktivitas antikanker apabila memiliki nilai $\mathrm{IC}_{50}<30 \mu \mathrm{g} / \mathrm{ml}$, moderate aktif apabila memiliki nilai $30 \leq \mathrm{IC}_{50} \leq 100 \mu \mathrm{g} / \mathrm{ml}$ dan tidak aktif apabila nilai $I C_{50}>100 \mu \mathrm{g} / \mathrm{ml}$ (Putram, Setyaningsih, Tarman, \& Nursid, 2017). Hasil analisis memperlihatkan bahwa ekstrak teripang H.atra
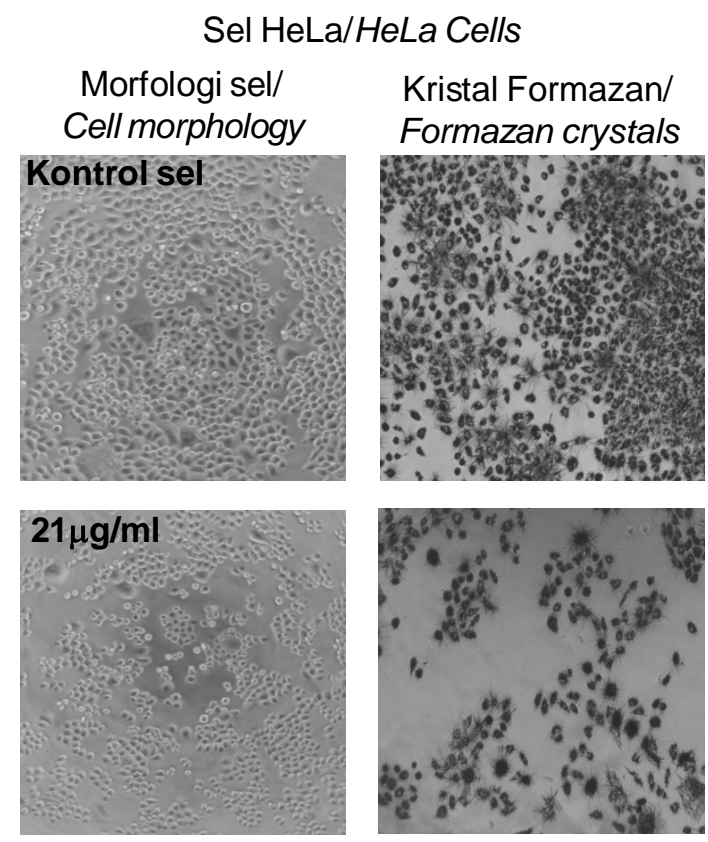

Sel WiDr/WiDr Cells
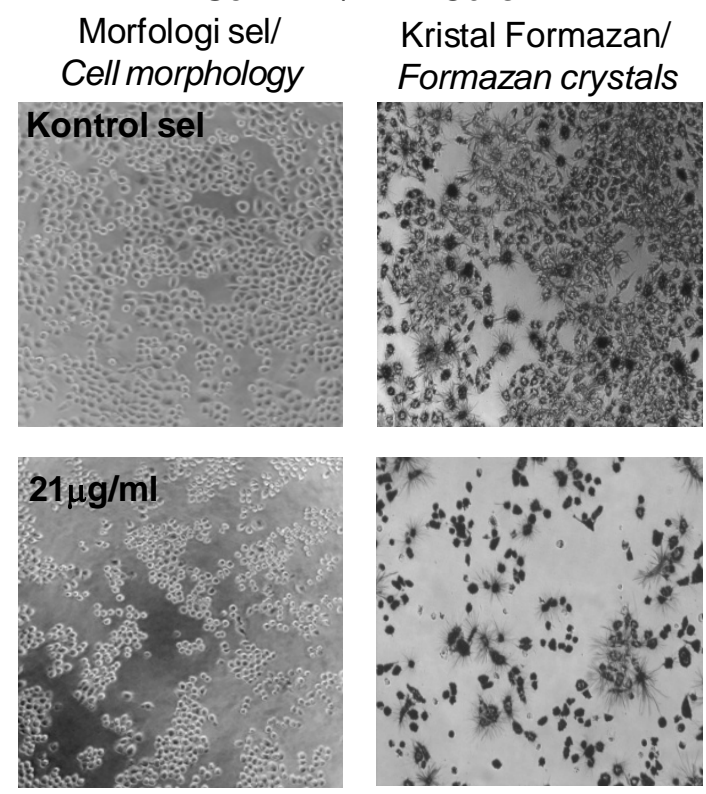

Kristal Formazan/

Formazan crystals
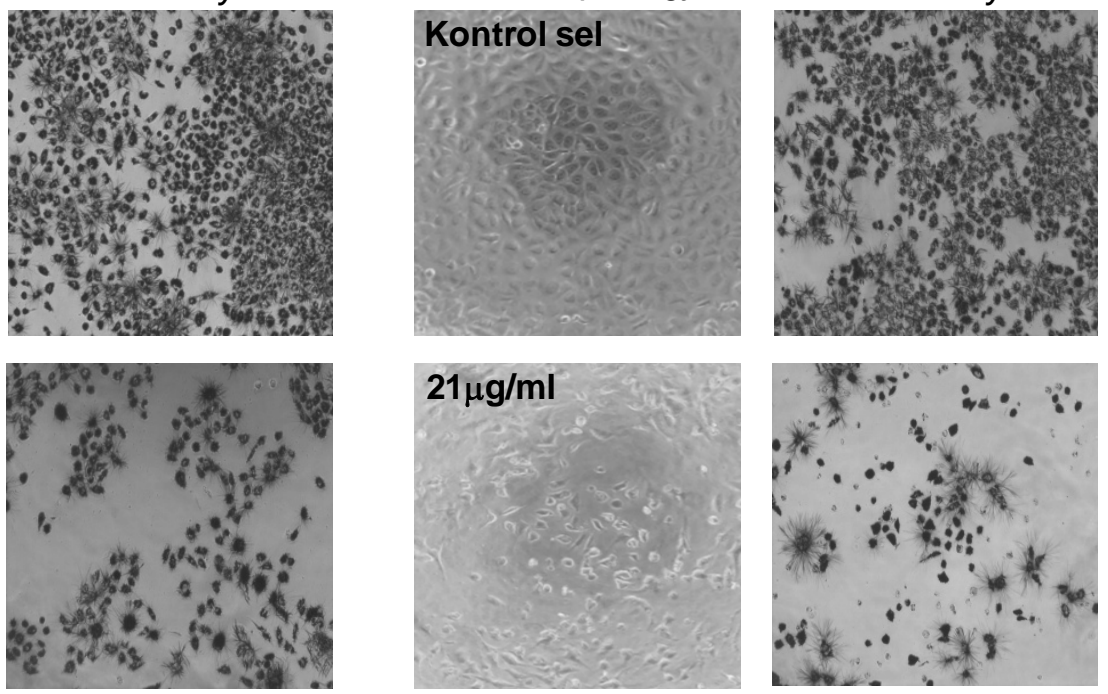
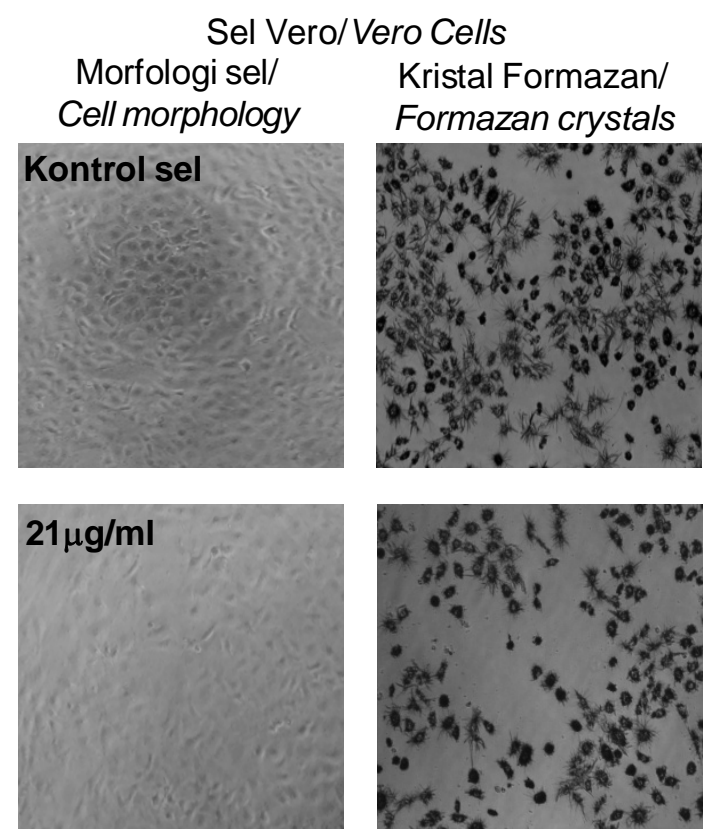

Gambar 2. Morfologi sel kanker dengan perlakuan ekstrak etanol teripang H. atra pada konsentrasi $21 \mu \mathrm{g} / \mathrm{ml}$. Figure 2. Cancer cell morphology treated by $21 \mu \mathrm{g} / \mathrm{ml}$ ethanol extract of sea cucumber $\underline{\mathrm{H}}$. atra 
Tabel 2. Nilai $I_{50}$ ekstrak etanol teripang $H$. atra terhadap beberapa jenis sel dan indeks selektivitasnya (IS) Table 2. IC $C_{50}$ value of ethanol extract of sea cucumber $\underline{H}$ atra on cancer cell lines and their selectivity Index (SI)

\begin{tabular}{crc}
\hline Jenis Sel/Cell Type & $\begin{array}{r}\mathbf{I C}_{\mathbf{5 0}}(\boldsymbol{\mu g} / \mathbf{m I}) / \\
\boldsymbol{I C}_{\mathbf{5 0}}(\boldsymbol{\mu g} / \mathbf{m I})\end{array}$ & $\begin{array}{c}\text { Indeks selektivitas (IS)/ } \\
\text { Selectivity Index (SI) }\end{array}$ \\
\hline Sel HeLa/HeLa Cells & $41.06 \pm 4.21$ & 3.13 \\
Sel T47D/T47D Cells & $20.89 \pm 1.55$ & 6.12 \\
Sel WiDr/WiDr Cells & $26.50 \pm 4.43$ & 4.83 \\
Sel Vero/Vero Cells & $128.00 \pm 2.98$ & 1.00 \\
\hline
\end{tabular}

termasuk dalam kategori aktif terhadap sel T47D dan WiDr dengan nilai $I_{50}$ sebesar $20,89 \pm 1,55$ dan $26,50 \pm 4,43 \mu \mathrm{g} / \mathrm{ml}$, serta moderat aktif pada sel HeLa dengan $\mathrm{IC}_{50}$ sebesar $41,06 \pm 4,21 \mu \mathrm{g} / \mathrm{ml}$ (Tabel 2). Nilai $\mathrm{IC}_{50}$ ekstrak terhadap sel Vero sebesar $128,00 \mu \mathrm{g} / \mathrm{ml}$. Dhinakaran dan Lipton (2014) melaporkan bahwa ekstrak metanol $H$. atra yang diperoleh dari perairan Samudra Hindia memiliki aktivitas sitotoksik pada sel HeLa dengan nilai $\mathrm{IC}_{50}$ sebesar $468 \mu \mathrm{g} / \mathrm{ml}$ dan pada sel MCF-7 dengan nilai $\mathrm{IC}_{50}$ sebesar $352 \mu \mathrm{g} / \mathrm{ml}$.

Selectivity Index diperoleh dari nilai $\mathrm{IC}_{50}$ suatu senyawa terhadap sel normal dibagi dengan nilai $\mathrm{IC}_{50}$ terhadap sel kanker (Demirgan et al., 2016). Sel normal yang digunakan adalah sel Vero. Sel Vero berasal dari ginjal monyet hijau Afrika, sel ini merupakan sel kultur yang berasal dari mamalia (Ammerman, Beier-Sexton, \& Azad, 2008). Pengujian dengan menggunakan sel Vero dapat memberikan perkiraan sitotoksisitas terhadap sel normal manusia. Nilai $\mathrm{SI}>2,0$ berarti bahwa suatu senyawa dianggap memiliki selektivitas yang tinggi. Semakin tinggi indeks selektivitas suatu senyawa terhadap sel, maka senyawa tersebut semakin selektif dalam mematikan atau menghambat pertumbuhan suatu sel kanker dengan efek yang semakin kecil terhadap sel normal (Demirgan et al., 2016). Berdasarkan nilai $I_{50}$ dan nilai SI, maka sel T47D digunakan dalam penelitian berikutnya untuk mengetahui efek ekstrak teripang dalam kemampuannya menginduksi apoptosis.

\section{Uji Apoptosis dengan Analisis Flowcytometric}

Pengujian apoptosis ini menggunakan FITC Annexin V Apoptosis Detection Kit II. Prinsip dari kit ini adalah menggunakan Annexin $\mathrm{V}$ yang berkonjugasi dengan fluorescein isothyocyanate (FITC) untuk mengikat phosphatidylserine (PS) pada permukaan sel yang mengalami apoptosis (Gambar 3). Phosphatidylserine (PS) merupakan aminofosfolipid yang akan berpindah posisi dari membran internal ke membran eksternal pada saat apoptosis. Annexin V adalah protein yang memiliki afinitas tinggi terhadap fosfolipid yang bermuatan negatif dengan adanya ion $\mathrm{Ca}^{2+}$. Kalsium yang terdapat dalam Annexin $\mathrm{V}$ tersebut mampu mengikat Phospatidilserine (PS) yang berada di luar membran plasma yang mengalami apoptosis.Translokasi PS pada permukaan sel

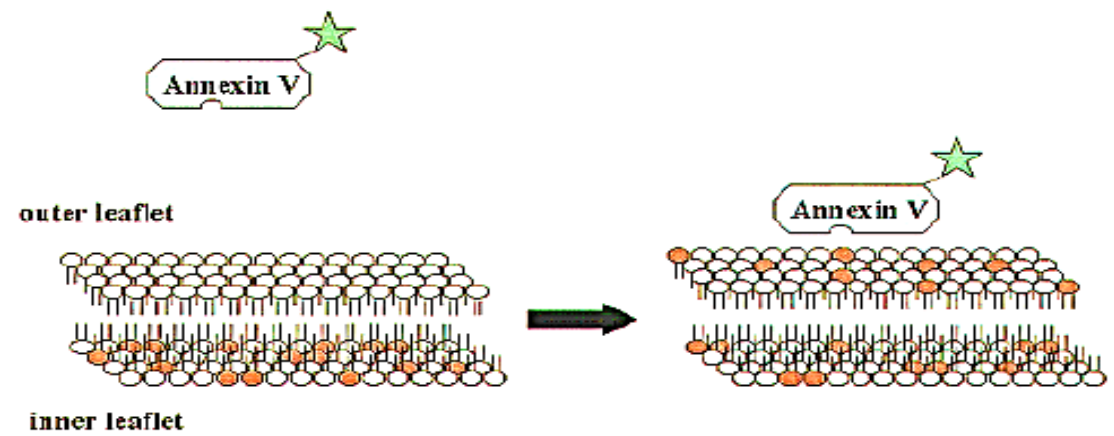

\section{Normal cell}

Apoptotic cell

Gambar 3. Skema pengikatan Annexin V terhadap membran sel yang mengalami apoptosis (Engeland, Nieland, Ramaekers, Schutte, \& Reutelingsperger, 1998).

Figure 3. Scheme of Annexin $V$ binding to cell membranes undergo apoptosis (Engeland, Nieland, Ramaekers, Schutte, \& Reutelingsperger, 1998). 

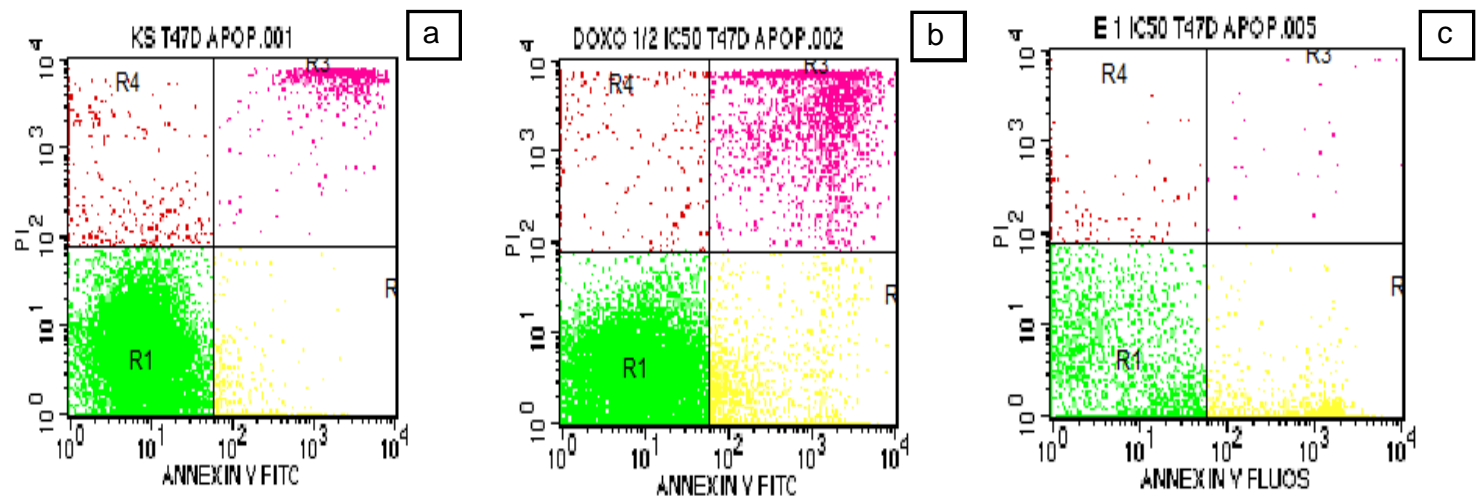

Keterangan :(a) kontrol sel (b) doksorubisin $0,1 \mu \mathrm{g} / \mathrm{ml}$ (c) ekstrak etanol teripang $H$. atra dengan konsentrasi $20 \mu \mathrm{g} / \mathrm{ml}$.

Description: (a) cell control (b) doxorubicin $0.1 \mu \mathrm{g} / \mathrm{ml}$ (c) ethanol extract of sea cucumber $\underline{\mathrm{H}}$. atra with concentration of $20 \mu \mathrm{g} / \mathrm{ml}$.

Gambar 4. Hasil analisis flowcytometric

Figure 4. Results of flowcytometric analysis

menjadikan ikatan Annexin $\mathrm{V}$ sebagai penanda apoptosis (Crowley, Marfell, Scott, \& Waterhouse, 2016).

Penambahan Propidium lodida $(\mathrm{PI})$ pada sel kanker digunakan sebagai penanda terjadinya nekrosis. Rangkaian pemberian Annexin V- FITC dan $\mathrm{PI}$ ini dapat membedakan sel yang hidup, sel yang mengalami apoptosis, dan sel yang mengalami nekrosis. Analisis tersebut dapat dilakukan dengan menggunakan flowcytometer (Nursid, Namirah, Cahyana, \& Fajarningsih, 2015).

Analisis flowcytometry pada penelitian ini menggunakan dosis sebesar $20 \mu / \mathrm{ml}$. Dosis ini digunakan karena nilai IC ${ }_{50}$ ekstrak terhadap sel T47D berkisar $20 \mu \mathrm{g} / \mathrm{ml}$ (Tabel 2), sehingga diharapkan pada dosis ini sel yang hidup maupun yang apoptosis dapat dibedakan. Hasil analisis flowcytometry (Gambar 4) menunjukkan bahwa persentase kematian sel dengan mekanisme apoptosis lebih besar dibandingkan dengan nekrosis pada ekstrak $H$. atra maupun pada doksorubisin. Ekstrak etanol teripang $H$. atra dengan konsentrasi $20 \mu \mathrm{g} / \mathrm{ml}$ dapat menginduksi apoptosis sebesar $82,06 \%$ pada sel payudara T47D. Ekstrak teripang $\mathrm{H}$. atra memiliki persentase apoptosis lebih besar dibandingkan dengan doksorubisin karena mekanisime doksorubisin yang berbeda. Doksorubisin merupakan agen kemoterapi yang digunakan pada penderita kanker payudara dengan mekanisme interkelasi DNA dan menghambat topoisomerase II sehingga mengakibatkan penghambatan sintesis DNA (Thorn et al., 2011). Nilai persentasi apoptosis, nekrosis, dan sel yang tetap hidup dapat dilihat pada Tabel 3.

\section{Analisis Apoptosis dengan Double Staining}

Pengamatan secara visual pada sel yang mengalami apoptosis dapat dideteksi dengan pengecatan menggunakan akridine oranye-etidium

Tabel 3. Hasil analisis flowcytometric

Table 3. Results of flowcytometric analysis

\begin{tabular}{|c|c|c|c|c|}
\hline \multirow[b]{2}{*}{ Sampel/ Sample } & \multicolumn{3}{|c|}{ Persentase/Percentage (\%) } & \multirow[b]{2}{*}{$\begin{array}{l}\text { Nekrosis/ } \\
\text { Necrosis }\end{array}$} \\
\hline & $\begin{array}{l}\text { Sel yang hidup/ } \\
\text { Live cells }\end{array}$ & $\begin{array}{l}\text { Apoptosis awal/ } \\
\text { Early apoptotic }\end{array}$ & $\begin{array}{l}\text { Apoptosis akhir/ } \\
\text { Late apoptotic }\end{array}$ & \\
\hline Kontrol sel/Cell control & 91.89 & 2.46 & 3.89 & 1.80 \\
\hline $\begin{array}{l}\text { Doksorubisin/Doxorubicin } \\
(0.1 \mu \mathrm{g} / \mathrm{ml})\end{array}$ & 73.33 & 15.04 & 10.27 & 1.46 \\
\hline $\begin{array}{l}\text { Ekstrak etanol teripang } H \text {. } \\
\text { Atra/Ethanol extract of sea } \\
\text { cucumber } \underline{H} \text {. atra }(20 \mu \mathrm{g} / \mathrm{ml})\end{array}$ & 17.18 & 82.06 & 0.15 & 0.65 \\
\hline
\end{tabular}



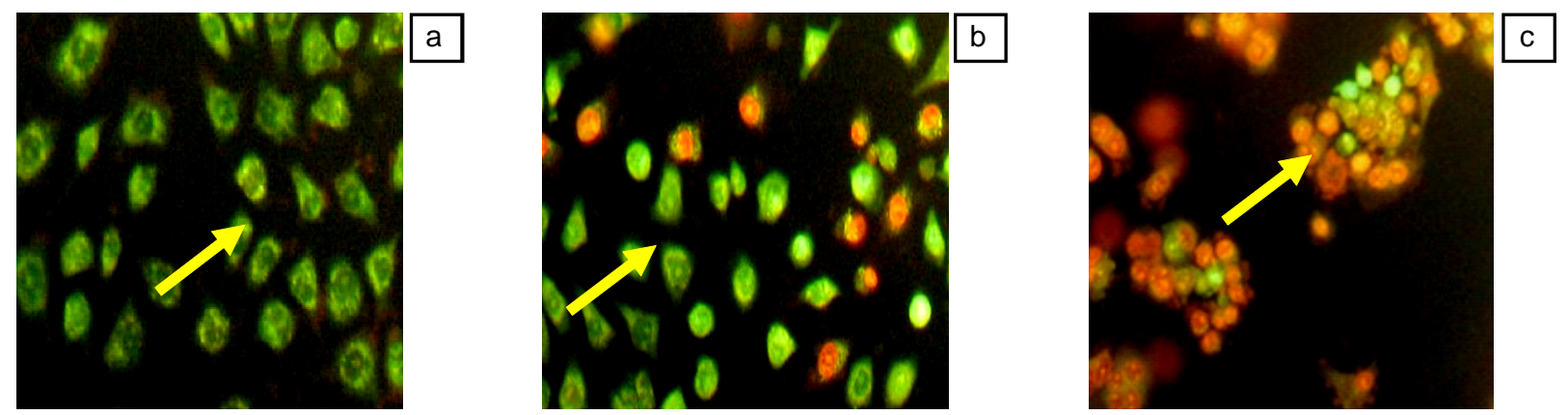

Keterangan : (a) kontrol sel (b) doksorubisin $0,1 \mu \mathrm{g} / \mathrm{ml}$ (c) ekstrak etanol teripang $H$. atra dengan konsentrasi $20 \mu \mathrm{g} / \mathrm{ml}$.

Description : (a) cell control (b) doxorubicin $0.1 \mu \mathrm{g} / \mathrm{ml}$ (c) ethanol extract of sea cucumber of $\underline{\mathrm{H}}$. atra with concentration of $20 \mu \mathrm{g} / \mathrm{ml}$.

Gambar 5. Hasil pengamatan Apoptosis Sel T47D menggunakan mikroskop fluoresens (perbesaran 100x) Figure 5. Result of T47D cell apoptosis using fluorescent microscope (magnification of 100x)

bromida (Kwan et al., 2015). Metode ini berdasarkan fluoresensi DNA pada sel yang hidup dan sel yang mati karena adanya pengikatan akridine oranyeetidium bromida. Pada hasil pengamatan terlihat bahwa kontrol sel (Gambar 5a) berwarna hijau. Warna hijau berasal dari akridine oranye yang menembus seluruh bagian sel hidup dengan membran yang utuh dan memiliki nukleus. Pada sel yang diberi perlakuan doksorubisin dan ekstrak teripang $H$. atra (Gambar $5 b$ dan 5c) terdapat warna oranye yang menggambarkan sel T47D yang mati. Warna oranye tersebut disebabkan karena etidium bromida yang berinterkelasi dengan sel rusak pada membran dan nukleus (Ribble, Goldstein, Norris, \& Shellman, 2005). Warna oranye pada perlakuan ekstrak (Gambar 5c) lebih banyak dibandingkan dengan doksorubisin (Gambar 5b). Berdasarkan persentase sel yang mengalami apoptosis pada data Tabel 3, sel T47D yang mengalami apoptosis setelah diberikan perlakuan ekstrak $H$.atra berjumlah $82,06 \%$. Sedangkan jumlah persentase sel yang mengalami apoptosis setelah diberikan doksorubisin hanya $15,04 \%$. Hal tersebut yang menyebabkan warna oranye pada sel T47D yang diberi perlakuan ekstrak lebih dominan dibanding pada sel perlakuan doksorubisin.

Hasil uji secara umum menunjukkan bahwa ekstrak teripang H.atra memiliki kemampuan menghambat pertumbuhan sel kanker terutama pada sel kanker T47D. Kemampuan penghambatan tersebut melalui mekanisme apoptosis yang dibuktikan melalui pengujian flowcytometry dan analisis double staining. Kedua hasil analisis tersebut dapat menggambarkan mekanisme kematian sel yang disebabkan karena adanya apoptosis baik secara kuantitatif maupun secara kualitatif. Induksi apoptosis menjadi suatu hal yang menjanjikan dalam pengobatan kanker. Pada sel kanker, sel akan mengalami kehilangan kemampuan apoptosis dan sel berproliferasi sangat cepat. Strategi pengobatan ini dapat mengembalikan jalur sinyal apoptosis menjadi normal sehingga berpotensi untuk menghilangkan sel kanker (Wong, 2011).

\section{KESIMPULAN}

Ekstrak etanol teripang Holothuria atra Jaeger, 1833 mempunyai aktivitas sitotoksisitas terhadap beberapa sel kanker yaitu sel HeLa, T47D dan WiDr dengan $\mathrm{IC}_{50}$ masing-masing sebesar $41,06 \pm 4,21$; $20,89 \pm 1,55$ dan $26,50 \pm 4,43 \mu \mathrm{g} / \mathrm{ml}$, namun memiliki sitotoksisitas yang lebih rendah terhadap sel Vero dengan nilai $I C_{50}$ sebesar $128,00 \mu \mathrm{g} / \mathrm{ml}$. Penghambatan terbesar terjadi pada sel T47D, dengan mekanisme penghambatan sel tersebut melalui induksi apoptosis.

\section{UCAPAN TERIMAKASIH}

Penulis mengucapkan terima kasih kepada Balai Besar Riset Pengolahan Produk dan Bioteknologi Kelautan dan Perikanan (BBRP2BKP) dan Universitas Muhammadiyah Surakarta yang telah memfasilitasi dan membiayai penelitian ini.

\section{DAFTAR PUSTAKA}

Althunibat, O. Y., Ridzwan, B. H., Taher, M., Daud, J. M., Jauhari Arief Ichwan, S., \& Qaralleh, H. (2013). Antioxidant and cytotoxic properties of two sea cucumbers, Holothuria edulis lesson and Stichopus horrens Selenka. Acta Biologica Hungarica, 64(1), 1020. https://doi.org/10.1556/ABiol.64.2013.1.2

Ammerman, N. C., Beier-Sexton, M., \& Azad, A. F. (2008). Growth and maintenance of vero cell line. Curr Protoc Microbiol,1-10.https://doi.org/10.1002/ 9780471729259.mca04es11. 
Sitotoksisitas dan Induksi Apoptosis Ekstrak Etanol Teripang Holothuria atra........(Ernie Halimatushadyah et al.,)

Azwanida. (2015). A Review on the extraction methods use in medicinal plants, principle, strength, and limitation. Medical \& Aromatic Plants, 4(3), 3-8. https:/ /doi.org/10.4172/2167-0412.1000196

Bordbar, S., Anwar, F., \& Saari, N. (2011). High-value components and bioactives from sea cucumbers for functional foods - A review. Marine Drugs, 9(10), 17611805. https://doi.org/10.3390/md9101761

Caulier, G., Dyck, S., Gerbaux, P., Eeckhaut, I., \& Flammang, P. (2011). Review of saponin diversity in sea cucumbers belonging to the family Holothuriidae. SPC Beche-de-Mer Information Bulletin, 31(January), 48-54.

Chasanah, E. (2008). Marine biodiscovery research in indonesia: challenges and rewards. Journal of Coastal Development, 12(1), 1-12.

Chasanah, E., Januar, H. I., \& Nursid, M. (2014). Cytotoxic saturated fatty acids from the Indonesian sea cucumber Holothuria sp. Squalen Bull. of Mar. \& Fish. Post. \& Biotech., 9(1), 11-15. https://doi.org/ 10.15578/squalen.v9i1.69

Crowley, L. C., Marfell, B. J., Scott, A. P., \& Waterhouse, N. J. (2016). Quantitation of apoptosis and necrosis by Annexin $\mathrm{V}$ binding, propidium iodide uptake, and flow cytometry. Cold Spring Harbor Protocol, 953-958. https://doi.org/10.1101/pdb.prot087288

Demirgan, R., Karagöz, A., Pekmez, M., Önay-Uçar, E., Artun, F. T., Gürer, Ç., \& Mat, A. (2016). In vitro anticancer activity and cytotoxicity of some papaver alkaloids on cancer and normal cell lines. African Journal of Traditional, Complementary and Alternative Medicines, 13, 22-26. https://doi.org/http:/ /dx.doi.org/10.4314/ajtcam.v13i3.3

Dhinakaran, D. I., \& Lipton, A. P. (2014). Bioactive compounds from Holothuria atra of Indian ocean. SpringerPlus, 4, 673. https://doi.org/10.1186/21931801-3-673

Donepudi, M. S., Kondapalli, K., Jeevan, A. S., \& Pavithra, V. (2014). Breast cancer statistics and markers. Journal of Cancer Research and Therapeutics, 10(3). https://doi.org/10.4103/0973-1482.137927

Ebada, S. S., Edrada, R. A., Lin, W., \& Proksch, P. (2008). Methods for isolation, purification and structural elucidation of bioactive secondary metabolites from marine invertebrates. Nature Protocols, 3(12), 19-23. https://doi.org/10.1038/nprot.2008.182

Engeland, M. Van, Nieland, L. J. W., Ramaekers, F. C. S., Schutte, B., \& Reutelingsperger, C. P. M. (1998). Annexin V-Affinity Assay/: A Review on an apoptosis detection system based on Phosphatidylserine exposure. Cytometry, 9(31), 1-9.

Freshney, R. I. (2005). Culture of animal cells: a manual of basic technique (Fifth Fdit). John Wiley \& Sons.

Harbone, J. (1987). Metode fitokimia, penuntun cara modern menganalisis tumbuhan. Penerbit ITB Bandung.

Husain, G., Tamanampo, J. F. W. , \& Manu, G. D. (2017). Struktur komunitas teripang (Holothuridae) di kawasan Pantai Pulau Nyaregilaguramangofa Kec. Jailolo Selatan Kab. Halmahera Barat Maluku Utara. Jurnal IImiah Platax, 5(2), 177-188

Hussain, S., Fareed, S., Ansari, S., \& Sajid, M. (2012). Marine natural products/ : a lead for anti-cancer. Indian
Journal of Geo-Marine Sciences, 41(February), 2739.

Kemenkes, R. (2013). Riset Kesehatan Dasar (RISKESDAS) 2013. Jakarta.

Kwan, Y. P., Saito, T., Ibrahim, D., Al-hassan, F. M. S., Oon, C. E., Chen, Y., ... Sasidharan, S. (2015). Evaluation of the cytotoxicity, cell-cycle arrest, and apoptotic induction by Euphorbia hirta in MCF-7 breast cancer cells. Pharmaceutical Biology, O(0), 114. https://doi.org/10.3109/13880209.2015.1064451

Li, Y. X., Himaya, S. W. A., \& Kim, S. K. (2013). Triterpenoids of marine origin as anti-cancer agents. Molecules, 18(7), 7886-7909. https://doi.org/10.3390/ molecules 18077886

Mulrane, L., Mcgee, S. F., Gallagher, W. M., Mulrane, L., Mcgee, S. F., Gallagher, W. M., \& Connor, D. P. O. (2013). miRNA Dysregulation in breast cancer miRNA dysregulation in breast cancer. American Association for Cancer Research. https://doi.org/10.1158/00085472.CAN-13-1841

Nursid, M., Chasanah, E., Murwantoko, \& Wahyouno, S. (2011). Isolation and identification of emestrin from Emericella nidulans and investigation of its anticancer properties. Microbiology Indonesia, 5, 160-169. https://doi.org/10.5454/mi.5.4.3

Nursid, M., Namirah, I., Cahyana, A. H., \& Fajarningsih, N. D. (2015). Emestrin B/ : Epipolythiodioxypiperazine from marine derived fungus Emericella nidulans. Journal of Medical and Bioengeneering, 4(6), 441445. https://doi.org/10.12720/jomb.4.6.441-445

Putram, N. M., Setyaningsih, I., Tarman, K., \& Nursid, M. (2017). Aktivitas antikanker dari fraksi aktif teripang. JPHPI, 20, 53-62. https://doi.org/10.17844/ jphpi.2017.20.1.53

Rachmani, E. P. N., \& Sehesti, T. S. (2012). The Breast of Anticancer from leaf extract of Annona muricata againts cell line in T47D. International Journal of Applied Science and Technology, 2(1), 157-164.

Ribble, D., Goldstein, N. B., Norris, D. A., \& Shellman, Y. G. (2005). A simple technique for quantifying apoptosis in 96-well plates. BMC Biotechnology, 7, 1-7. https://doi.org/10.1186/1472-6750-5-12

Sutejo, I. R., Putri, H., \& Meiyanto, E. (2016). Selektivitas ekstrak etanolik buah makassar (Brucea javanica) pada kanker payudara metastasis secara In Vitro. Journal of Agromedicine and Medical Sciences, 2(1), 1-5.

Thorn, C. F., Oshiro, C., Marsh, S., Boussard, T. H., McLeod, H. L., Klein, T. E., \& Altman, R. B. (2011). Doxorubicin pathways: pharmacodynamics and advers effect. Pharmacogenet Genomics, 21(7), 440446 . h t t p s://d o i.org/10.1097/ FPC.0b013e32833ffb56.Doxorubicin

WHO. (2018). WHO Cancer. Retrieved January 4, 2018, from http://www.who.int/news-room/fact-sheets/ detail/cancer

Wong, R. S. Y. (2011). Apoptosis in cancer/ : from pathogenesis to treatment. Journal of Experimental \& Clinical Cancer Research, 30(1), 87. https://doi.org/ 10.1186/1756-9966-30-87 
JPB Kelautan dan Perikanan Vol. 13 No. 2 Tahun 2018: 101-110 